\title{
KAJIAN KEBIJAKAN DAGING SAPI DI INDONESIA UNTUK MENDUKUNG SWASEMBADA DAGING SAPI
}

\author{
Kusmaria \\ Program Studi Agribisnis, Politeknik Negeri Lampung, Lampung \\ Email: kusmaria@polinela.ac.id \\ Susanti \\ Program Studi Produksi Ternak, Politeknik Negeri Lampung \\ Email: susantisukses@polinela.ac.id \\ Annisa Fitri \\ Program Studi Agribisnis Pangan, Politeknik Negeri Lampung, Lampung \\ Email: annisafitrihasibuan@polinela.ac.id \\ Sri Handayani \\ Program Studi Agribisnis, Politeknik Negeri Lampung, Lampung \\ Email: sri.handayani84@polinela.ac.id
}

\begin{abstract}
Abstrak
Pertambahan jumlah penduduk di Indonesia menjadi salah satu faktor pendorong pelaksanaan program swasembada daging sapi. Beberapa upaya dilakukan oleh pemerintah demi mencapai program swasembada daging sapi. Penelitian ini bertujuan mengkaji sejauh mana program-program yang dilakukan untuk mencapai program swasembada daging sapi. Metode yang dilakukan berupa studi literatur. Banyaknya program Kementrian Pertanian yang dicanangkan membuat Kementrian Pertanian tidak fokus dalam pelaksanaan program, sehingga tidak ada satupun komoditi yang berhasil swasembada. Kontrol jumlah sapi di Indonesia masih diperankan oleh importir. Program swasembada daging perlu dikaji ulang, mengingat program swasembada daging ini justru merugikan negara Indonesia dimana banyaknya pihakpihak yang tidak bertanggung jawab memanfaatkan program swasembada daging sebagai ranah untuk korupsi. Pemerintah sebaiknya fokus terhadap program swasembada yang benar-benar mungkin dicapai, tidak terlalu banyak menargetkan swasembada. Pemerintah sebaiknya memuat target jangka pendek, menengah, dan panjang untuk pratinjau ulang pentingnya swasembada sapi.
\end{abstract}

Kata Kunci: Daging Sapi, Kebijakan, Swasembada

\begin{abstract}
The increasing number of population in Indonesia is the one of factor that driving the implementation of self-sufficience on beef. Several methods were done by Government to reach the sufficiency program on beef. This research is aimed to examine the extend of program are carried out to reach self-sufficience on beef. The method used is in the form of literature study. The many programs that launched by the ministry of Agriculture caused them unfocus on implementing the programs, so none of the commodities managed to be self-sufficient. The control of the number of cattle in Indonesia is still played by the importers. The self-sufficient programs on beef needs to be reviewed, while this program is actually detrimental to Indonesia which is many irresponsibility of some party that abusing this program as a chance to do corruption. The government should be focus on self-sufficient program that are really possible to be reached, not targeting too much of self-sufficient. The government should include the short, medium, and long-term targets to preview the importance of self-sufficient on beef.
\end{abstract}

Keywords: Beef, Policy, Self-sufficient

\section{PENDAHULUAN}

Laju peningkatan penduduk indonesia peningkatan kebutuhan protein hewani dan perubahan selera konsumen akan mendorong peningkatan kebutuhan pangan dan konsumsi teradap peningkatan konsumsi protein hewani. Komoditas daging telur dan susu adalah komoditas pangan yang memiliki protein yang tinggi (Priyanto, 2005). Berdasarkan data dari Departemen Pertanian, komoditas daging sapi merupakan komoditas yang paling banyak diminati jika dibandingkan dengan komoditas daging lainnya seperti daging kambing, kebau dan babi (Pakpahan, 2012). 
Kebutuhan konsumsi daging sapi penduduk Indonesia cenderung terus meningkat sejalan dengan meningkatnya jumlah penduduk Indonesia dan kesadaran masyarakat akan pentingnya protein hewani tersebut, sehingga laju permintan daging sapi ini meningkat. Peningkatan permintaan daging sapi ini tidak diimbangi oleh peningkatan produksi daging sapi dalam negri sehingga ketersediaan daging sapi nasional masih mengalami kekurangan. Kekurangan pasokan daging sapi di Indonesia cukup besar dan memicu besarnya import ternak dari beberapa negara. Berdasarkan data dari UN Comtrade (2018) impor daging sapi di Indonesia dari tahun 2010 hingga tahun 2018 berfluktuatif dan cenderung mengalami peningkatan. Volume Impor daging sapi di Indonesia dapat dilihat pada Gambar 1.

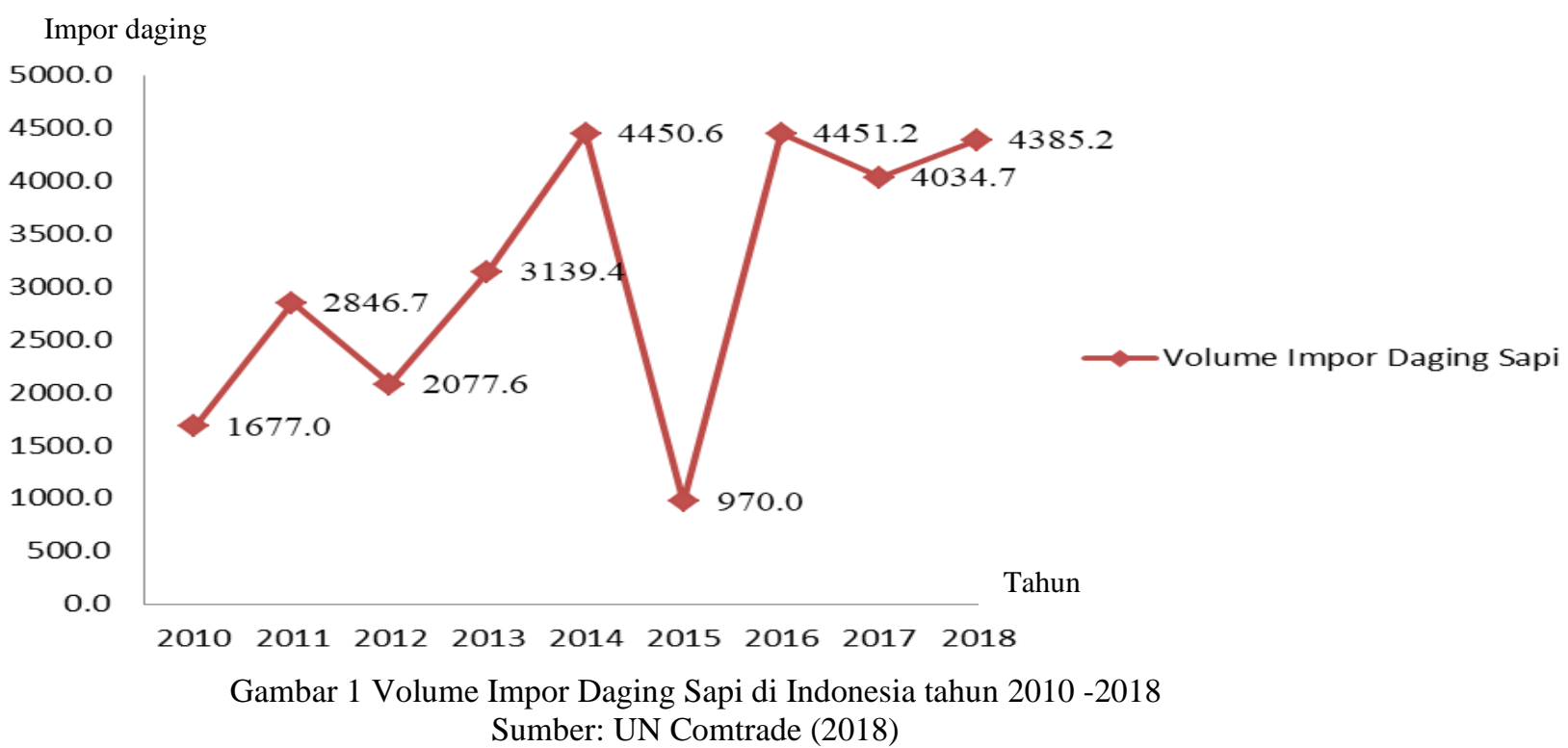

Demi mengurangi impor yang setiap tahunnya meningkat, pemerintah mencanangkan programprogram pencapaian swasembada daging sapi berbasis sumberdaya domestik. Program nasional untuk swasembada daging sapi sebenarnya merupakan ketiga kalinya yang dicanangkan pemerintah. Program pencapaian swasembada daging sapi ini telah lama dicanangkan pemerintah yaitu pada tahun 2000 program kecukupan daging sapi dengan target capaian tahun 2005. Namun belum berhasil, kemudian disusul dengan program baru yaitu program percepatan swasembada daging sapi (P2SDS) dengan target pencapaian pada tahun 2010. Tetapi pada tahun 2009 daging dan sapi impor justru mengalami peningkatan mencapai $51 \%$ lebih tinggi dari tahun sebelumnya. Berdasarkan dari kegagalan-kegagalan program swasembada daging sapi sebelumnya, perlu dikaji kebijakan program swasembada daging sapi yang dilakukan sudah optimal.

\section{METODE}

Tulisan ini merupakan telaah terhadap teori-teori dan program yang berhubungan dengan program swasembada daging di Indonesia. Program swasembada daging, dibahas secara detail berdasarkan data dan fakta. Data dan informasi diperoleh melalui hasil-hasil penelitian terdahulu. 


\section{HASIL DAN PEMBAHASAN}

\section{Program Kecukupan Daging Sapi 2005}

Berawal dari tidak terpenuhinya kebutuhan daging sapi secara domestik yang berimplikasi pada peningkatan impor serta pengurasan devisa negara, untuk mengatasi hal tersebut pemerintah mencanangkan program swasembada daging sapi pada tahun 2000 yaitu program kecukupan daging sapi dengan target capaian tahun 2005. Isi dari program kecukupan daging sapi 2005 menurut Basuno et al., (2011) tersebut adalah :

a. Peningkatan produktivitas melalui :

1) Kegiatan ET dan IB diikuti IB terpadu

2) Upaya persilangan ke arah dual purposes

3) Pengembangan sentra baru kawasan

b. Peningkatan populasi ternak dengan cara :

1) Pengendalian pemotongan betina produktif

2) Pengendalian penyakit reproduksi

3) Penyediaan bibit ternak bermutu/impor bibit ternak

c. Subsitusi dan diversifikasi produk

d. Pembinaan dan pengembangan kelembagaan melalui :

1) Perbaikan kinerja UPT pembibitan

2) Pengembangan kelembagaan penangkar bibit ternak rakyat (oleh rakyat sendiri) semacam $\mathrm{VBC}$

e. Desentralisasi BIB

f. Pembentukan Puspinak

g. Promosi dan pengembangan ekspor produk dan pengamanan ternak

Program kecukupan daging sapi 2005 ini tidak berhasil dicapai oleh pemerintah dikarenakan program ini tidak disertai dengan rencana yang rinci dan kegiatan riil dilapangan yang belum terealisasi. Menurut Yusdja et al. (2004) dalam Priyanto (2011), ketidakberhasilan swasembada daging yang dicanangkan pada tahun 2000 dan berakhir pada 2004 sudah menunjukkan ketidak berhasilan disebabkan tidak tercapainya sasaran program. Penyebabnya adalah:

a. Kebijakan program tidak disertai dengan rencana operasional yang rinci dan kegiatan riil di lapangan.

b. Program bersifat top down dan berskala kecil dibandingkan dengan sasaran yang ingin dicapai.

c. Strategi implementasi program disamaratakan dengan tidak memprioritaskan wilayah unggulan, tetapi berorientasi pada komoditas unggulan.

d. Implementasi program tidak memungkinkan untuk mengevaluasi dampak program, dan

e. Program tidak secara jelas memberikan dampak pada pertumbuhan populasi ternak secara nasional. 


\section{Program Percepatan Swasembada Daging 2010}

Gagalnya target swasembada daging sapi tahun 2005 tidak membuat pemerintah berputus asa dalam pencapaian swasembada daging sapi. Pada tahun 2005 pemerintah mencanangkan kembali program swasembada daging yaitu program percepatan swasembada daging sapi 2010. Isi dari program tersebut menurut Basuno et al., (2011) adalah :
a. Optimalisasi akseptor dan kelahiran IB/KA
b. Pengembangan RPH dan pengendalian pemotongan sapi betina produktif
c. Perbaikan mutu bibit
d. Penanganan gangguan reproduksi dan penyakit hewan
e. Pengembangan pakan lokal
f. INKA
g. Pengembangan SDM dan kelembagaan ditambah kegiatan pendukung
h. Melakukan pendekatan ekonomis dengan pengendalian impor daging sapi/bakalan.

Seperti halnya pada tahun 2005, program percepatan swasembada daging sapi ini juga tidak berhasil. Pemenuhan kebutuhan daging sapi lokal masih belum bisa dilakukan. Hal ini terlihat pada tahun 2009, daging dan sapi impor justru mencapai $51 \%$ lebih tinggi dari tahun sebelumnya. Pencapaian swasembada daging sapi ini merupakan tantangan yang tidak ringan, karena pada tahun 2009 impor daging mencapai 70 ribu ton dan sapi bakalan setara dengan 250,8 ribu ton daging (Ditjenak, 2010 dalam Rusono, 2011).

Kegagalan swasembada ini dinilai karena banyaknya pihak yang belum berhasil. Kegagalan ini disebabkan adanya berbagai permasalahan di lapangan baik yang berpengaruh langsung maupun yang berpengaruh tidak langsung terhadap implementasi swasembada daging sapi. Beberapa permasalahan yang menyebabkan tertundanya pencapaian swasembada daging sapi tersebut yaitu :

a. Kesenjangan produksi daging domestik dengan konsumsi terjadi tiap tahun yang diduga karena adanya peningkatan jumlah masyarakat kelas menengah ke atas.

b. Pasar sapi lokal rentan pengaruh pasar global, kondisi ekonomi pasar sapi domestik tidak stabil dan berpola acak, karena terjadi pengaruh yang sangat signifikan dari ekonomi pasar sapi dan daging luar negri. Beberapa variabel pasar global yang mempengaruhi kondisi ekonomi pasar sapi domestik antara lain : penawaran daging sapi, konsumsi dan harga daging sapi lokal, jumlah dan harga impor sapi dan daging sapi.

c. Produktivitas sapi lokal masih rendah

d. Persilangan sapi lokal tidak terprogram

e. Hambatan lompatan populasi sapi nasional

f. Masalah yang terkait dengan kelembagaan diantaranya eksekusi beberapa program seperti penyelamatan sapi betina produktif, penganan reproduksi, dan kesehatan hewan mengalami masalah di lapangan karena sistem pendanaan yang mengikuti pola APBN/APBD kurang cocok dengan kondisi di lapangan (Rusono, 2011). 


\section{Program Swasembada Daging Sapi 2014}

Impian pemerintah dalam hal pemenuhan kebutuhan daging sapi domestik tidak pernah berhenti meskipun telah mengalami kegagalan dua kali. Berbekal dukungan politik, dana, dan pengalaman di masa lalu maka kebijakan swasembada daging sapi dan kerbau dilakukan lagi dengan rancangan yang melibatkan berbagai pemangku kepentingan. Rancangan disusun dalam suatu dokumen berupa blue print (BP) Program Swasembada Daging Sapi (PSDS) 2014. PSDS 2014 disusun kedalam lima kegiatan pokok serta 13 kegiatan operasional. Kegiatan tersebut adalah :

a. Penyediaan bakalan/daging sapi lokal:

1) Pengembangan usaha pembiakan/penggemukan sapi lokal,

2) Pengembangan pupuk organik dan biogas,

3) Pengembangan integrasi ternak dan tanaman, dan

4) Pemberdayaan dan peningkatan kualitas RPH,

b. Peningkatan produktivitas dan reproduktivitas sapi lokal:

1) Optimalisasi IB dan INKA,

2) Penyediaan dan pengembangan pakan dan air, dan

3) Penanggulangan gangguan reproduksi dan peningkatan layanan keswan,

c. Pencegahan pemotongan sapi betina produktif:

1) Penyelamatan sapi betina produktif,

d. Penyediaan bibit sapi lokal:

1) Penguatan wilayah sumber bibit dan kelembagaan usaha pembibitan,

2) Pengembanan usaha pembibitan sapi potong melalui VBC,

3) Penyediaan sapi bibit melalui subsidi bunga, dan

e. Pengaturan stock daging sapi dalam negeri (DN):

1) Pengaturan stock sapi bakalan dan daging,

2) Pengaturan distribusi dan pemasaran sapi/daging (Ashari, dkk. 2012).

Program Swasembada Daging Sapi Tahun 2014 (PSDS-2014) ini merupakan salah satu program utama Departemen Pertanian terkait dengan upaya mewujudkan ketahanan pangan hewani asal ternak berbasis sumberdaya domestik. Program tersebut merupakan peluang untuk dijadikan pendorong dalam mengembalikan Indonesia sebagai eksportir sapi seperti pada masa lalu.

Salah satu indikator utama dalam swasembada daging sapi adalah populasi ternak sapi. Jika populasi ternak sapi mencukupi untuk kebutuhan konsumsi daging maka dianggap telah swasembada. Untuk PSDS 2014 diharapkan minimal 90\% konsumsi daging sapi dapat dipasok dari sapi domestik. Sisanya, 10\%, dipenuhi melalui impor baik dalam bentuk daging segar maupun bakalan (Priyanto, 2011).

Program Swasembada Daging Sapi Tahun 2014 (PSDS-2014) juga merupakan salah satu program prioritas pemerintah dalam lima tahun ke depan untuk mewujudkan ketahanan pangan asal ternak berbasis sumberdaya lokal. Pencapaian swasembada daging sapi ini merupakan tantangan yang tidak ringan, mengingat impor daging dan bakalan yang masih tinggi yang mencapai 70 ribu ton daging dan sapi bakalan yang setara 250,8 ribu ton daging selama tahun 2009. Angka tersebut diindikasikan ada kecenderungan yang terus meningkat. Begitu juga melihat pengalaman masa lalu, dimana Presiden Susilo 
Bambang Yudhoyono telah pernah mencanangkan pencapaian swasembada daging sapi tahun 2010 melalui upaya revitalisasi pertanian sebagai dasar untuk mengembangkan agribisnis sapi potong yang berdaya saing dan untuk sebesar-besarnya kemakmuran rakyat. Namun, program tersebut menghadapi banyak tantangan dan permasalahan, baik dari aspek teknis, ekonomi, sosial maupun kebijakan-kebijakan pendukungnya. Koordinasi antar instansi, antar sektor, serta antar pengemban kepentingan (stakeholder) juga masih sangat lemah, sehingga hal ini perlu mendapat perhatian untuk diselesaikan pada masa yang akan datang.

Belajar dari kegagalan, dan mengingat pelaksanaan Program Swasembada Daging Kerbau dan Sapi (PSDSK) 2014 yang relatif singkat yakni 4 tahun, diperlukan juga program terobosan yang mampu mendongkrak produksi daging nasional. Menurut Priyanto (2011) untuk mendukung PSDSK 2014 tersebut, beberapa program pendukung yang dilaksanakan yaitu :

1. Pengembangan sentra produksi sapi potong berbasis wilayah dimana usaha pembibitan perlu disesuaikan dengan padang pengembalaan.

2. Pengembangan aspek teknis dan teknologi, melalui introduksi teknologi dan kelembagaan serta sarana pendukung

3. Penyelamatan sapi betina produkif.

Program penyelamatan sapi betina produktif perlu didukung dengan program BLU (Badan Layanan Umum) yang berfungsi membeli sapi betina produktif dari peternak untuk dikembalikan pada peternak. Perlu juga dilakukan perbaikan dan pengelolaan Rumah Potong Hewan (RPH).

4. Tunda potong untuk penggemukkan

Ternak lokal umumnya dipotong saat belum mencapai bobot optimal, sehingga menghasilkan karkas/daging yang rendah. Rekomendasi tunda potong merupakan salah satu alternatif dalam mendukung pertambahan bobot potong dan bobot daging yang dihasilkan sehingga akan meningkatkan produksi daging.

5. Memperpendek jarak beranak, melalui penyediaan pejantan unggul di lapangan, mempertepat deteksi berahi, dan melakukan penyuluhan sistem perkawinan sehingga peternak mampu mengawinkan ternak tepat pada waktu.

6. Pengembangan teknologi inseminasi buatan ((IB)

Selain peningkatan ketersediaan inseminasi buatan di lapangan diperlukan juga kebijakan pendukung berupa pendistribusian IB secara selektif karena berdasarkan penelitian Priyanto (2005), teknologi IB tidak berpengaruh terhadap penyediaan daging dikarenakan tidak tersedianya dan tidak seimbangnya distribusi semen beku.

7. Pengembangan model Integrasi

Merupakan salah satu efisiensi usaha untuk meningkatkan pendapatan petani dengan usaha multi komoditas (ternak dan tanaman). Dengan kebijakan ini akan meningkatkan daya dukung pakan dimana peternak memanfaatkan limbah pertanian untuk ternak, dan kotoran ternak untuk pupuk kompos sehingga menekan biaya produksi 
8. Pengembangan kelembagaan

Dalam pengembangan kelembagaan, anggota kelompok dibina dalam inovasi teknologi, pengembangan sarana dan prasarana, pemenuhan target produksi dalam hal pemasaran hasil secara kontinu, dan penghimpunan modal kelompok, sehingga dengan terbentuk kelompok yang mantap maka akan terbentuk usaha yang berorientasi bisnis yang mampu meningkatkan posisi tawar produk.

9. Pembatasan impor daging

Perlunya dilakukan pembatasan impor secara bertahap untuk menjamin pertumbuhan peternakan rakyat serta mendukung kelancaran program swasembada daging 2014 ini.

Untuk mencapai sasaran program swasembada daging sapi nasional pada tahun 2014, berbagai kebijakan dan program yang dicanangkan oleh pemerintah secara umum bertujuan untuk menambah populasi sapi dan produktivitas sapi, dengan mengembangkan potensi persapian Indonesia (nasional) yang sekarang ada. Kebijakan penambahan populasi dan produktivitas sapi bertujuan untuk menambah kemampuan penyediaan (produksi) daging sapi nasional. Jumlah daging sapi yang harus disediakan, ditentukan oleh kebutuhan konsumsi daging sapi penduduk secara nasional. Sementara kebutuhan konsumsi daging sapi nasional ditentukan oleh jumlah penduduk dan konsumsi daging sapi per kapita masyarakat Indonesia. Sejalan dengan pertumbuhan penduduk dan semakin meningkatnya kesadaran masyarakat akan pentingnya protein hewani, maka kebutuhan daging sapi nasional juga akan cenderung semakin meningkat (Dwiyanto , 2008).

\section{PERLUKAH PROGRAM SWASEMBADA DAGING SAPI}

Definisi swasembada adalah Indonesia tidak akan mengimpor daging sapi sama sekali alias tingkat impornya nol persen, ternyata definisi swasembada daging sapi bukan seperti itu menurut Kementrian Pertanian, hal ini terlihat dari target swasembada daging sapi 2014 yaitu minimal $90 \%$ konsumsi daging sapi dapat dipasok dari sapi domestik. Sisanya $10 \%$ dipenuhi melalui impor baik dalam bentuk daging segar maupun sapi bakalan. Apabila seperti itu, untuk apa pemerintah menggunakan terminologi "swasembada". Ide swasembada pangan, khususnya beras pada Pak Harto dalam Rencana Pembangunan Lima Tahun Pertama (Repelita I) disebutkan bahwa peningkatan produksi pangan bertujuan agar Indonesia dalam lima tahun ke depan tidak perlu mengimpor beras (Dzulfian, 2013). Definisi swasembada pada Repelita I tersebut, jelas yang dimaksud oleh Pak Harto dengan swasembada adalah Indonesia tidak lagi mengimpor beras sama sekali (nol persen). Jadi apakah sebenarnya makna dari penggunaan kata swasembada yang dimaksud pemerintah Indonesia pada saat sekarang?

Program swasembada sapi ini sudah pernah dua kali gagal, apabila dipaksakan swasembada daging lagi di tahun selanjutnya apakah Indonesia sudah siap? Sebaiknya target swasembada daging ditinjau ulang oleh pemerintah. Menurut Sarman (ketua komite daging sapi), Indonesia terlalu berambisi mencapai swasembada daging sapi 2014, namun tanpa aksi nyata (Nurhayat, 2012). Belajar dari kenyataan sebelumnya, target swasembada daging sapi tahun 2005 dan 2010 hasilnya gagal. Kementrian Pertanian harus membuat rencana jangka panjang untuk menyediakan stok daging sapi, sehingga tidak terjadi kelangkaan. 
Permasalahan terkait daging sapi di Indonesia masih terus terjadi karena keinginan pemerintah mengejar target swasembada daging sapi, tanpa diimbangi dengan kemampuan produksi. Target swasembada daging sapi sebaiknya ditinjau ulang agar tidak menganggu komoditas lain yang juga dicanangkan untuk swasembada. Menurut Budiyono (2010) Kementerian Pertanian Republik Indonesia menetapkan sasaran strategis dalam Pembangunan Pertanian Tahun 2010-2014, yakni pertama: ditetapkannya sasaran 39 komoditas unggulan nasional : Tanaman Pangan (7), Hortikultura (10), Perkebunan (15), dan Peternakan (7); kedua : ditetapkannya sasaran swasembada untuk 5 (lima) komoditas, yakni : Padi (swasembada berkelanjutan), Jagung (swasembada berkelanjutan), Kedelai (swasembada 2014), Gula (swasembada 2014), dan Daging Sapi (swasembada 2014).

Banyaknya program Kementrian Pertanian yang dicanangkan membuat Kementrian Pertanian tidak fokus dalam pelaksanaan program sehingga tidak ada satupun komoditi yang berhasil swasembada. Semuanya ditargetkan untuk swasembada seperti program swasembada beras, swasembada jagung, swasembada kedelai, dan swasembada gula. Menurut Nurhayat (2012), tidak fokusnya Kemetrian Pertanian dalam membuat rencana jangka panjang berdampak pada tidak ada satupun dari lima komoditi (beras, jagung, gula, kedelai, daging) yang mencapai swasembada.

Disamping tidak fokusnya pemerintah karena terlalu banyak komoditi yang ditargetkan untuk swasembada, banyak juga terjadi permainan politik dalam hal swasembada daging ini, yang pada akhirnnya bisa menyebabkan swasembada tidak tercapai dan justru menjadi ranah korupsi bagi pihak yang tidak bertanggung jawab. Adanya perbedaan data jumlah kebutuhan dan realisasi impor menjadi celah pada permainan terkait pelaksanaan Program Swasembada Daging Sapi (PSDS). Sebagaimana hasil penelitian Basuno et al (2011) distribusi sapi bakalan dan daging impor ini rawan praktek curang (penyeludupan).

Menurut Dzulfian (2013) adanya kejanggalan dalam bisnis impor daging sapi ini disebabkan harga impor daging Australia jauh lebih mahal dibanding sapi Brazil yang mana kualitasnya tidak jauh berbeda. Brazil 2 USD/kg sedangkan Australia 4 USD/ kg. Padahal secara logika jauh lebih menguntungkan jika impor dari Brazil. Adanya kebijakan pemangkasan daging impor selain merugikan importir juga merugikan negara-negara seperti Australia dan lainnya yang menjadikan Indonesia sebagai pasar daging sapi negara-negara tersebut juga tidak akan tinggal diam karena kebijakan quota daging.

Asosiasi Ekonomi Politik Indonesia, menduga kelangkaan pasokan serta naiknya harga daging sapi juga disebabkan oleh permainan para importir. Pemangkasan kuota impor dalam jumlah yang besar dari 100 ribu ton daging sapi di tahun 2011 menjadi 34 ribu ton sapi di tahun 2012 telah merugikan para importir tersebut.Dengan demikian tidak menutup kemungkinan para importir dengan sengaja membuat kelangkaan pasokan. Jika dilihat tidak ada satupun dari fenomena ekonomi yang bisa menyebabkan kenaikan sedemikian tinggi. Kenaikan harga daging tidak wajar, setelah Idul Adha seharusnya turun, tetapi justru naik padahal tidak ada masalah ekonomi yang signifikan. Jika masalah pasokan daging disebabkan oleh kebijakan swasembada daging sapi, yaitu dengan penurunan kuota impor secara dratis, tapi menurut data, pasokan daging sapi ada dan aman.

Diduga kelangkaan sapi ini disengaja untuk menggagalkan tercapainya swasembada daging. Dengan langkanya daging sapi akan menyebabkan harga jual tinggi, meskipun pemerintah menerapkan kebijakan 
perlindungan sapi produktif dengan pemberian insentif pada peternak, namun dengan tidak adanya sanksi hukum yang tegas dan adanya bisnis sapi yang menggiurkan yaitu harga daging sapi sedang mahal. Peternak memilih untuk memotong sapi produktif agar mendapatkan keuntungan lebih. Sehingga ketersediaan sapi lokal produktif akan berkurang bahkan bisa habis, pada akhirnya para importir akan selalu melakukan impor untuk pemenuhan kebutuhan daging dalam negeri.

Tidak akan bisa mencapai swasembada, jika daging impor selalu dimainkan importir dan tidak ada kebijkan hukum yang tegas. Kekurangan daging sapi, bisa saja beralih ke unggas ataupun domba. Jadi jangan menjadi alasan bagi pemerintah untuk memaksakan daging sapi impor masuk ke Indonesia.

Masalah adanya kelangkaan daging sapi juga dikarenakan masalah distribusi, dimana lokasi sentra produksi besar itu mayoritas di tempat timur Indonesia sedangkan konsumsi terbesar di barat Indonesia, meskipun peningkatan produksi sapi berhasil, jika pendistribusian sapi tersebut tidak lancar tetap saja permintaan sapi tidak dapat terpenuhi. Dengan jarak yang cukup jauh membutuhkan waktu serta alat angkut yang cukup dengan biaya transfortasi yang mahal untuk membawa sapi, padahal tujuan awal swasembada untuk menghemat devisa negara yang habis dikarenakan impor. Oleh karena itu dibutuhkan suatu kebijakan baru berupa diversifikasi pangan sebagai langkah strategis untuk mengurangi konsumsi daging sapi ini.

Pencapaian target swasembada dan banyaknya kecurangan dalam hal impor daging, distribusi sapi yang tidak lancar dan belajar dari kegagalan sebelumnya, program swasembada daging sapi ini tidak akan tercapai. Pemerintah banyak mengeluarkan kebijakan yang kontraproduktif dalam pelaksanaan program swasembada daging sapi. Pemerintah mendorong produksi sapi lokal namun, di sisi lain masih mengeluarkan kebijakan impor sapi secara bebas. Menurut Indonesia Research Strategic Analisys, untuk mencapai swasembada diperlukan perubahan pola fikir seluruh pemangku kepentingan (stakeholder). Peternakan sapi memiliki potensi besar untuk ekonomi nasional. Jadi, orientasinya harus bisnis. Sekarang pemerintah mendorong produksi sapi lokal namun, di sisi lain masih mengeluarkan kebijakan impor sapi secara bebas. Peraturan menteri pertanian no 20 tahun 2009 tentang pemasukan dan pengawasan peredaran karkas, daging, dan jeroan dari luar negeri menunjukkan perubahan pola fikir pemerintah dari ketahanan pangan menjadi liberalisasi pangan. Dengan membuka keran impor daging sebesar-besarnya, peternakan rakyat termasuk industri penggemukan sapi potong akan semakin tertekan karena harus bersaing untuk memperoleh pasar di negeri sendiri.

Terjadi peningkatan produksi sapi lokal tetapi dengan tingkat pertumbuhan penduduk yang setiap tahun bertambah, tidak mungkin swasembada daging ini tercapai. Bertambahnya penduduk kebutuhan akan daging juga akan meningkat. Misalnya target swasembada daging 100 ton tahun 2014, walaupun tahun 2014 produksi daging sapi tercapai 100 ton, jika tahun 2014 tersebut peningkatan penduduk tinggi tetap saja tidak mencukupi untuk memenuhi konsumsi dalam negeri.

Kebijakan penambahan populasi dan produktivitas sapi bertujuan untuk menambah kemampuan penyediaan (produksi) daging sapi nasional. Jumlah daging sapi yang harus disediakan, ditentukan oleh kebutuhan konsumsi daging sapi penduduk secara nasional. Sementara kebutuhan konsumsi daging sapi nasional ditentukan oleh jumlah penduduk dan konsumsi daging sapi per kapita masyarakat Indonesia. Sejalan dengan pertumbuhan penduduk dan semakin meningkatnya kesadaran masyarakat akan 
pentingnya protein hewani, maka kebutuhan daging sapi nasional juga akan cenderung semakin meningkat Dwiyanto (2008). Menurut penelitian Harmini, Asmarantaka, \& Atmakusuma (2011), program swasembada daging tidak tercapai pada tahun 2014 apabila konsumsi daging lebih tinggi lagi pada tahun tersebut.

Berdasarkan hal di atas, apakah Indonesia masih perlu swasembada daging? Peternak juga tidak yakin terhadap swasembada daging karena peternak berorientasi keuntungan, apabila produksi daging meningkat akan menurunkan harga jual yang diterima mereka. Dari hasil penelitian Hanafi (2011), mayoritas peternak belum yakin/ragu terhadap program swasembada daging sapi 2014. Mereka kurang percaya pada pemerintah dengan adanya situasi yang tidak berpihak pada peternak yaitu anjloknya harga penjualan sapi ditingkat masyarakat akhir-akhir ini yang berdampak terhadap menurunnya semangat dalam memelihara ternak. BPK (Badan Pemeriksa Keuangan) juga menemukan adanya kejanggalan terhadap program swasembada daging yang dilakukan oleh pemerintah. Adanya temuan oleh BPK dalam hal masalah program swasembada daging di Kementrian Pertanian, dimana terjadinya penyembelihan massal sapi betina produktif yang telah mencapai tingkat yang membahayakan (Dwi, Febi, 2013).

Perlunya kejelasan tujuan program swasembada ini apakah berpihak pada peternak yang mayoritas peternak kecil, apakah untuk melindungi konsumen atau melindungi kepentingan tertentu. Apabila pemerintah bertujuan untuk melindungi produsen agar kesejahteraannya meningkat, justru meningkatkan produksi daging sapi malah akan menurunkan semangat peternak karena otomatis harga daging akan turun dengan peningkatan penawaran. Tujuan swasembada ini untuk melindungi konsumen, konsumen manakah yang dilindungi pemerintah? karena tidak semua kalangan yang setiap harinya mengkonsumsi daging sapi. Permintaan akan daging sapi untuk masyarakat kalangan bawah hanya pada hari-hari tertentu seperti lebaran. Oleh karena itu jika harga daging sapi tinggi tidak akan masalah bagi konsumen, karena konsumen daging sapi mayoritas masyarakat kelas menengah ke atas bukan masyarakat menengah ke bawah yang semestinya jadi prioritas utama pemerintah dalam pengambilan kebijakan. Dengan tingginya harga sapi ini masyarakat kelas bawahlah yang dilindungi terutama para peternak miskin yang mempunyai peliharaan sapi.

Mahalnya harga sapi tidak terlalu berpengaruh pada konsumsi rumah tangga. Menurut Bustanul Arifin (2012), setiap pemangku kepentingan daging sapi termasuk pemerintah masih sulit bergeser atau tidak mau mengalah. Peternak skala kecil dan besar cenderung hati-hati memotong ternak, karena khawatir terhadap lonjakan harga sapi impor yang sulit diprediksi. Pedagang dan importir sapi juga tidak begitu saja melepas stok sapi. Kelompok industri pengolahan daging sapi dan produk turunannya menuntut penurunan harga daging. Sedangkan pemerintah sibuk membahas dan mengutak-atik kuota impor sapi, seakan terjebak dalam pencarian solusi jangka pendek dan terkesan melupakan langkah utama dalam pelaksanaan pencapaian target swasembada daging sapi itu sendiri. Sedangkan konsumen akhir di tingkat rumahtangga tidak bersuara lantang. Hal ini mencerminkan konsumen rumahtangga tidak terlalu risau atas tingkat harga daging sapi, bisa memenuhi protein dari konsumsi lainnya.

Apabila masyarakat kelas menengah ke atas yang ribut dengan tingginya harga sapi tidak akan menjadi masalah jika pemerintah memang pro rakyat miskin. Jika mereka tidak mampu membeli harga daging sapi yang tinggi, mereka bisa beralih ke konsumsi yang lain (diversifikasi pangan) seperti ikan, 
belut dan lainnya yang kandungan gizinya tidak jauh berbeda jika dibanding dengan daging sapi. Tingginya harga daging sapi, konsumsi terhadap daging sapi akan berkurang dengan sendirinya. Selama masa penungguan bibit sapi menjadi besar dan siap untuk dipotong, Indonesia tidak perlu impor daging lagi karena konsumsi daging telah menurun dengan sendirinya dikarenakan tingginya harga dan juga karena diversifikasi pangan pada daging ikan dan belut. Pada akhirnya Indonesia bisa mencapai tidak hanya swasembada daging sapi tapi bahkan menjadi negara pengekspor daging sapi lagi seperti pada tahun 1979 yang silam. Tetapi jika konsumennya lebih memilih mengkonsumsi daging sapi karena hal selera, itu persoalan lain. Tanpa mengkonsumsi daging sapi masyarakat Indonesia tidak akan kekurangan gizi, apalagi gizi ikan, telur, dan belut yang banyak tersedia di Indonesia tidak jauh berbeda dengan gizi daging sapi. Hal ini bisa dilihat pada tabel di bawah.

Tabel 1. Kandungan Energi Daging Belut, Telur, dan Sapi

\begin{tabular}{|l|l|}
\hline Keterangan & Kandungan Energi \\
\hline Belut & 330 kkal per 100 gram daging \\
\hline Telur & 162 kkal per 100 gram tanpa kulit \\
\hline Sapi & 207 kkal per 100 gram \\
\hline
\end{tabular}

Sumber : Winarno (2002)

Oleh karena itu, apabila kita bertujuan untuk menghemat devisa negara yang terbatas dengan pengurangan ketergantungan pada impor, perlu kebijakan lain dalam hal daging sapi ini. Dengan kebijakan swasembada daging, peternak juga tidak yakin dalam hal swasembada daging dan swasembada daging ini juga tidak akan tercapai apabila konsumsi terhadap daging semakin meningkat. Salah satu kebijakan yang memungkinkan yaitu diversifikasi pangan, sehingga dengan diversifikasi pangan ini konsumsi terhadap daging tidak meningkat terus.

Penerapan kebijakan diversifikasi pangan ini bisa diterapkan dengan cara mensosialisasikan kepada masyarakat untuk tidak hanya terfokus mengkonsumsi daging sapi tetapi bisa mengkonsumsi daging yang lainnya. Disinilah peran penyuluhan, baik penyuluh pertanian, peternakan maupun penyuluh kesehatan untuk menjelaskan pada masyarakat bahwa mengkonsumsi ikan, dan belut sama gizinya dengan mengkonsumsi daging sapi bahkan lebih tinggi lagi (belut). Berdasarkan Tabel 1 nilai gizi, ikan tidak jauh berbeda dengan daging sapi, apalagi Indonesia memiliki laut yang luas, ikan cukup banyak di Indonesia. Begitu juga halnya daging belut. Daging belut punya nilai energi yang jauh lebih tinggi dibanding telur dan daging sapi. Dengan mulai beralihnya masyarakat mengkonsumsi ikan atau belut (diversifikasi pangan), konsumsi daging sapi akan berkurang sehingga kita tidak perlu tergantung pada impor, bahkan kita bisa ekspor daging lagi seperti masa lalu.

\section{PENUTUP}

\section{Simpulan}

Volume impor daging sapi yang setiap tahunnya semakin meningkat berimplikasi pada devisa negara, oleh karena itu pemerintah melakukan kebijakan swasembada daging sapi. Pelaksanaan program 
swasembada banyaknya kecurangan dalam hal impor daging, distribusi sapi yang tidak lancar, adanya kejanggalan yaitu terjadinya pemotongan massal sapi produktif dalam jumlah yang membahayakan di Kementrian Pertanian, kurangnya minat peternak untuk meningkatkan produksi sapi (karena produksi meningkat berimplikasi pada turunnya harga), dan tidak fokusnya pemerintah dalam pelaksanaan program swasembada yang dicanangkan (dimana selain program swasembada daging pemerintah juga mencanangkan program swasembada beras, jagung, kedelai dan gula), diduga program swasembada akan mengalami kegagalan seperti tahun-tahun sebelumnya.

Meskipun pemerintah berhasil meningkatkan produksi sapi lokal, tetapi bila pemerintah tidak bisa menyeimbangkan kebutuhan daging sapi terhadap tingkat pertumbuhan penduduk maka permintaan akan daging sapi tetap saja tidak akan terpenuhi. Hal ini dikarenakan kebutuhan konsumsi daging sapi nasional ditentukan oleh jumlah penduduk dan konsumsi daging sapi per kapita masyarakat Indonesia. Sejalan dengan pertumbuhan penduduk, maka kebutuhan daging sapi nasional juga akan cenderung semakin meningkat. Untuk mengatasi hal ini tidak bisa hanya dengan kebijakan pengurangan jumlah penduduk melalui program KB yang sampai saat ini masih belum berhasil. Perlu kebijakan lain berupa diversifikasi pangan atau keragaman pangan dimana masyarakat tidak hanya terfokus mengkonsumsi daging sapi tetapi bisa mengganti daging sapi dengan ikan, belut dan lainnya, sehingga konsumsi terhadap daging sapi berkurang dan pada akhirnya tidak diperlukan lagi impor daging sapi dari negara lain. Oleh karena itu, program swasembada daging tidak perlu dilaksanakan, program swasembada daging ini justru merugikan negara sendiri dimana banyaknya pihak-pihak yang tidak bertanggung jawab memanfaatkan program swasembada daging sebagai ranah untuk korupsi.

\section{Saran}

1. Sebaiknya pemerintah fokus terhadap program yang benar-benar mungkin dicapai, tidak terlalu banyak menargetkan swasembada (beras, jagung, kedelai, gula dan daging)

2. Sebaiknya pemerintah mencari cara lain untuk mengatasi permasalahan persapian ini, apalagi mengingat pertambahan jumlah penduduk berpengaruh negatif terhadap tercapainya pemenuhan daging sapi.

3. Sebaiknya pemerintah melakukan program jangka pendek melalui kebijakan diversifikasi pangan untuk pengurangan jumlah konsumsi daging sapi.

4. Perlunya ketegasan hukum dan pengawasan dalam pelaksanaan program, baik itu dalam hal swasembada maupun dalam hal pelaksanaan impor.

\section{DAFTAR PUSTAKA}

[Un Comtrade] United Commodity Trade. (2018). Commodity Statistic. Retrieved from https://comtrade.un.org/data/

Basuno, N. I. E., Ashari, W. K. S. S. N., \& Elizabeth, F. B. M. D. R. (2011). Keragaan, permasalahan dan upaya mendukung akselerasi program swasembada daging sapi. Bogor.

Budiyono, H. (2010). Analisis Neraca Perdagangan Peternakan dan Swasembada Daging Sapi 2014. Jurnal Agribisnis Dan Pengembangan Wilayah, 1(2).

Bustanul Arifin. (2012). Momentum Perbaikan Swasembada Daging Sapi. 
Dwi, Febi, S. (2013). BPK Temukan Banyak Masalah Program Swasembada Daging di Kementan. Detik Finance. Retrieved from Detik Finance.com

Dwiyanto K. (2008). Pemanfaatan Sumber Daya Lokal dan Inovasi Teknologi dalam Mendukung Pengembangan Sapi Potong di Indonesia. Pengembangan Inovasi Pertanian, 3, 173-188.

Dzulfian, S. (2013). Swasembada dan Daging Sapi. Institute for Development of Economics and Finance. Kompasmania. Retrieved from https://www.kompasiana.com/dzulfiansyafrian/55286acf6ea83467238b45ac/swasembada-dan-dagingsapi

HANO HANAFI, T. K. dan D. H. S. (2011). PENGKAJIAN RESPON PETERNAK TERHADAP PROGRAM ISTIMEWA YOGYAKARTA ( Assessment of Farmer Response to Beef Self Sufficiency Program 2014 in DIY ). 250-255. Seminar Nasional Teknologi Peternakan dan Veteriner.

Harmini, H., Asmarantaka, R. W., \& Atmakusuma, J. (2011). Model Dinamis Sistem Ketersediaan Daging Sapi Nasional. Jurnal Ekonomi Pembangunan: Kajian Masalah Ekonomi Dan Pembangunan, 12(1), 128. https://doi.org/10.23917/jep.v12i1.211

Nurhayat, W. (2012). Komite Daging: Target Swasembada Sapi Sudah Dua Kali Gagal Total. Detik Finance. Retrieved from https://finance.detik.com/berita-ekonomi-bisnis/2102333/komite-dagingtarget-swasembada-sapi-sudah-dua-kali-gagal-total

Pakpahan, A. R. S. (2012). Analisis Faktor-Faktor Yang Mempengaruhi Impor Daging Sapi Di Indonesia. Economics Development Analysis Journal, 1(2). https://doi.org/10.15294/edaj.v1i2.471

Priyanto, D. (2005). Evaluasi Kebijakan Impor Daging Sapi melalui Analisis Penawaran dan Permintaan. Jurnal Seminar Nasional Teknologi Peternakan Dan Veteriner, 275-284.

Priyanto, D. (2011). Strategi Pengembangan USaha Ternak Sapi Potong dalam Mendukung Program Swasembada Daging Sapi dan Kerbau Tahun 2014. Strategi Pengembangan USaha Ternak Sapi Potong Dalam Mendukung Program Swasembada Daging Sapi Dan Kerbau Tahun 2014, 30(3), 108116. https://doi.org/10.21082/jp3.v30n3.2011.p108-116

Rusono. (2011). Kebijakan dalam Percepatan Pencapaian Swasembada Daging 2014. In Info Kajian BAPPENAS. Jakarta (ID).

Winarno, F. . (2002). Kimia Pangan dan Gizi. Jakarta: Gramedia.

[Un Comtrade] United Commodity Trade. (2018). Commodity Statistic. Retrieved from https://comtrade.un.org/data/ 